\title{
An Analysis of Northwestern University's Denial of Rights to and Recognition of College Football Labor
}

\author{
Ellen J. Staurowsky \\ Drexel University
}

\begin{abstract}
"Our language is the reflection of ourselves. A language is an exact reflection of the character and growth of its speakers." Cesar Chavez, farm worker, civil rights activist, labor leader
\end{abstract}

(Cesar Chavez Foundation, 2012)

In March of 2014, Northwestern University football players were declared employees and granted the right to collectively bargain and unionize under the National Labor Relations Act (NLRA) (College Athletes Players Association v. Northwestern University, 2014; Southall, Nagel, \& Staurowsky, 2014). Currently under review with the National Labor Relations Board (NLRB) in Washington, D.C., the University has argued that recognition of the players as employees violates long-standing precedent and overlooks the fact that athletes are like all other students on campus. Joined in their opposition to the finding of the NLRB regional director, Peter Sung Ohr (2014), by the National Collegiate Athletic Association (NCAA), the American Council on Education and other higher education associations, six Republican senators from the U.S. Committee on Health and Education Labor and Pensions and the U.S. House of Representatives Committee on Education and the Workplace, the Big Ten Conference, and others, their collective rationale is anchored in the NCAA's principle of "amateurism" and its companion, the "student-athlete". This essay unpacks three mythologies embedded in key arguments presented in Northwestern's request for review and the amici briefs that contest the ruling that college football players are employees through an analysis of language and use of terminology.

\section{Myth \#1: College Athletes Are Just Like All Other Students}

A familiar theme that emerges out of the opposition to college football players being recognized as workers is the logic that holds that "student-athletes are students, not

Staurowsky is with the Department of Sport Management, Drexel University, Philadelphia, PA. Address author correspondence to Ellen Staurowsky at ejs95@ drexel.edu. 
employees" who are no different than students who participate in extracurricular activities such as the debate team and marching band (Brief of the American Council on Education ..., p. 2). Apart from the obvious observation that neither college debaters nor marching band members have ever sought recognition as employees in the courts and that by itself would point to a distinction well worth noting, the representation of college football players as being exactly the same as members of the debate team and marching band powerfully obscures the efforts of players over the span of decades to be treated fairly and to be valued for their contributions to a multibillion-dollar industry.

By suggesting to the uninformed that college football players are like every other student, there is no necessity to look at the forces that brought the Northwestern players to form the College Athletes Players Association and to sign union cards. There is no call to reflect on what it means that college football players since the 1920s onward have sought relief for the same concerns that Northwestern football players put forward in their petition, namely workplace safety, financial security and fair compensation, health care protections, and reasonable access to education.

As a result of the imposition of the frame that college football players are just like the debaters and the band members, the inconvenience of the historical facts remain at a distance, unexplored and unexplained. There is no prompt to probe the contradiction that an enterprise that proclaims loudly and long that college football players are like all other students insists on cloaking any discussion regarding players in the term "student-athlete," a term that signals that something is amiss; otherwise, why the labeling, why the distinction? After all, debaters are debaters, musicians are musicians, but football players are "student-athletes."

Through the historical portal presented by the term "student-athlete," comparisons between college football players and debaters or band members are revealed to be superficial at best, intentionally contrived at worst, and misleading regardless. As Walter Byers (1995), the first full time executive director of the NCAA reported in his memoir, the term "student-athlete" is a fiction designed by NCAA authorities to avoid the consequences of worker compensation cases brought by college football players starting in the 1950s. The creation of the term was followed with a calibrated propaganda campaign the purpose of which was to infuse the term into the American lexicon through sports information offices and outward to the mass media (Finkel, Martin, \& Paley, 2013; Staurowsky \& Sack, 2005). As Byers (1995) reported,

We crafted the term "student-athlete" and soon it was embedded in all NCAA rules and interpretations as a mandated substitute for such words as players and athletes. We told college publicists to speak of "college teams", not football and basketball "clubs", a word common to the pros (p. 69).

The flickering understanding that college football players were employees and worthy of being covered by workers compensation gained momentum in the 1950s and 1960s in the aftermath of the NCAA's adoption of the "grant-in-aid" (a.k.a., athletic scholarship) in 1951, a regulatory scheme acknowledged at the time as a "pay for play" system that rewarded athletic talent and compensated athletes for it. Byers (1996) credited University of Michigan athletic director, Fritz Crisler, with stating, "We're saying these youngsters are amateur and nobody 
should be permitted to professionalize them except the colleges. The colleges can pay them to play" (p. 74). This reservation of the right to pay athletes constrained by terms and conditions dictated by the NCAA under the guise of amateurism is reflected in the rules that govern college football player compensation and the college football labor force. While promoting the mirage that college sport is grounded in amateurism, setting the stage for athletes to participate by virtue of NCAA definition as an avocation (love of the game and as a recreational pursuit) and not vocation (a job), a close examination of NCAA bylaws reveals something far different. Note, for example, that the NCAA does not oppose pay to athletes but pay that it does not control. Consider NCAA Bylaw 12.02.8 which reads, "Pay is the receipt of funds, awards, and benefits not permitted by the governing legislation of the Association for participation" (NCAA Academic and Membership Affairs Staff, 2014, p. 58) and that athletes are rendered "professional" and therefore ineligible under NCAA rules only when they receive pay that is not permitted by the Association. Without this stipulation, the carefully engineered construction of pay linked as it is to athlete avocation and not job, the NCAA could not explain this otherwise irreconcilable circumstance that it is running a so-called amateur sport entity while paying athletes at the same time through the grant-in-aid and now a growing number of "benefits" programs. Thus, the tolerance for levels and manner of pay as well as how and in what ways athletes gain and retain access to pay is left to the devices of college sport officials to determine, acting on authority that as Crisler points out, they assigned unto themselves in their own self-interest.

The underlying context that serves as the backdrop for these rules is the reality that college football players have received payment for services rendered on the field in some form or fashion in every college sport era while struggling to have their value in the marketplace appropriately recognized and their status as employees affirmed. From the days of tramp athletes and ringers in the late 1800 s to modern day football players like the University of Georgia running back, Todd Gurley, who was punished in the fall of 2014 by the NCAA for accepting more than $\$ 3,000$ for autographing merchandise (Staples, 2014), underground economies have operated alongside of authorized player compensation schemes as accommodations to a business model of college sport that suppresses the value of its labor force, setting the value of college football players at zero as part of a price fixing arrangement (Schwartz, 2014), and avoiding the issuance of a paycheck (Sack \& Staurowsky, 1998). Within the college football industry, the athletic scholarship, with its careful calculation of payments for room and board, tuition, and fees, effectively serves as a capped form of compensation (Jenkins v. NCAA, 2014).

Regulating how, when, and under what circumstances college players receive payment has been a defining preoccupation of the NCAA, with the result being ultimate control over the labor force that generates approximately $95 \%$ of the college sport industry's revenue, namely college football and men's basketball players in the major programs. Flowing from the compensation scheme and denial of employee status are a full set of rules designed to regulate an unnamed college football labor force. Player access to advocacy is shut off through the no-agent rule and player movement is managed through transfer rules that require players to seek and obtain permission from coaches to go to other programs with coaches having the option to turn down requests or determine which programs players go to. 
Unlike NU football players, who are governed by the rules of the NCAA and the Big Ten, there is no national governing body for debaters or musicians dictating the limits on the number of scholarships they receive, the terms and conditions of those scholarships, or the number of hours they are permitted to participate in their activity. Due to NCAA rules pertaining to athlete transfers, which restrict the movement of players from one team to another, an NU football player who desired to transfer to another institution would need to ask permission to do so from his coach and be prepared that the coach might not permit a transfer or would dictate which schools the athlete could transfer to. In contrast, no member of a debate team or marching band is subjected to the same restrictions. ${ }^{1}$

\section{Myth \#2: College Football Players Cannot Be Paid Because They Are Students}

The Big Ten noted in its brief that the NLRB decision is an affront to its "first principle," that being that the "Conference recognizes the transcendent priority of a student-athlete's academic collegiate experience. It places its highest values upon high academic values. The student-athlete is student first, athlete second" (p. 12). The Big Ten's assertion in this regard not only strategically eludes the history of the term student-athlete, it further ignores the reality that athletes, as NLRB regional director Ohr did acknowledge, are not recruited to play football and receive athletic scholarships because of their academic skills but because of their athletic talents. One need only go to the Wildcat Digest on 247sport.com, whose media partner is CBS Sports, where the recruiting classes for the major college football programs, including Northwestern, are tracked on a year round basis. With 1,216,376 Facebook likes as of this writing, the site is used as a platform to preview high school talent and track where they are going in the college football marketplace through the Northwestern 2015 Commits List, a platform that serves as an advertising vehicle for numerous global corporations, include Air Canada, Comcast Business, Hilton Hotels \& Resorts, Hudl.com, J. M. Smucker Company, Litteman Jewelers, and Walmart. There is no class of students who are monetized in this fashion before, during, and after they attend college. College athletes are alone in the distinction of being denied the status as employees and therefore denied the possibility of realizing their full value in this kind of commercial marketplace.

Further, such an assertion ignores the fact that while college football players are denied employee status, $80 \%$ of undergraduate students in a study conducted by Citigroup were found to hold down part-time jobs that require them to work approximately 20 hours per week during the time that they are going to school ${ }^{2}$ (Fottrell, 2013). In the case of Northwestern football players, the record is clear that they work at their sport anywhere from 60 hours during preseason and more than 40 hours during the regular season. If they do not comport themselves in accordance with workplace expectations, showing up on the job in a timely fashion, prepared to work when they are there, being totally focused on the task at hand, they risk the prospect of being fired (dismissed from the team). Their handbook notes the requirements imposed on them that, in another universe apart from the one constructed by NCAA rules, would be immediately identified as workplace expectations. 


\section{Myth \#3: Denying College Football Players Status and Rights as Employees Preserves the "Revered Tradition of Amateurism"}

When the NCAA and its member institutions have been challenged because of their collective business practices, they have sought shelter in U.S. Supreme Court Justice Stevens' opinion in the 1984 Board of Regents case that found the NCAA guilty of violating antitrust law by limiting the number of games that college football teams could play on television. In that ruling, Justice Stevens refers to college sport amateurism as a "revered tradition" (NCAA v. Board of Regents, 1984, p. 32).

As revered as the tradition might be, at a practical level the NCAA, proven to be a formidable force in defining the landscape of college sport, has avoided defining what or who an amateur is. Search the expanse of the more than 400-page tome which is the NCAA Manual and it is silent on the question of what an amateur is, the word only used as an adjective, never as a noun. Further, in keeping with the tradition of NCAA rebranding efforts, the NCAA moved away from referring to college sport as "amateur athletics" in the mid-2000s and toward the use of the expression "the collegiate model of athletics" because of public charges of hypocrisy (Southall \& Staurowsky, 2013).

About amateurism, Byers (1995) wrote: "Amateurism is not a moral issue; it is an economic camouflage for monopoly practice" (p. 376). Hard pressed to sell the concept of amateurism to an increasingly skeptical public, the NCAA resorts to a tautology by repeating over and over that the reason college football players are amateurs is because they do not get paid. This tautology is given expression in exchange reported by Sports Illustrated columnist Michael Rosenberg and former NCAA President, Myles Brand, in 2010. The circular reasoning within the NCAA's current conception of amateurism is evidenced in the exchange:

Brand- "They can't be paid."

Rosenberg- “Why?”

Brand_- "Because they're amateurs."

Rosenberg- "What makes them amateurs?"

Brand-“Well, they can't be paid."

Rosenberg- "Why not?"

Brand-“Because they're amateurs."

Rosenberg - "Who decided they are amateurs?"

Brand_- "We did."

Rosenberg- "Why?"

Brand - "Because we don't pay them."

Devoid of any description of what makes a college athlete an amateur apart from the fact that they are not paid, the NCAA never offers an affirmative conception of what amateurism is, merely a singular prohibition that does not square with actual practice. Further, within the NCAA structure itself, different conceptions of amateurism reside, one next to the other. 
As Pierce, Kubarkas, and Fielding (2010) explain, NCAA member institutions encountered issues with certifying athletes from overseas who had received compensation for playing at a young age before realizing they wished to compete in U.S. colleges and universities in the 1990s. That problem led to the relaxation of NCAA amateurism standards and resulted in schools in Divisions II and III voting to grant permission to athletes from other countries who have received pay and/or competed professionally in their home countries to redeem their amateur standing. Division I schools, however, held the line and rejected that attempt. "The result is that previously paid international athletes are automatically eligible to compete in Division II and III athletics as amateurs, while the very same athletes are ineligible to compete in Division I athletics unless they succeed in obtaining what the NCAA calls reinstatement of their amateur status" (Staurowsky, 2013). According to Pierce et al. (2010), "Division I rejected legislation that would have permitted former professionals from competing in order to avoid negative public relations and legal consequences that may have resulted in the acceptance of those proposals" (p. 315).

And finally, NCAA members themselves lack a firm understanding of what amateurism means, revealing how malleable the principle is. In January 2008, NCAA Division I Vice-President David Berst conducted a study on amateurism among NCAA members. He found that it "was a definition that was not steeped in any sacred absolute principle that had to be preserved" (Staurowsky, 2013, p. 47). In sum, the NCAA's inability or unwillingness to offer a coherent conception of amateurism-in definition, in theory and in application-is tacit confirmation that big-time college athletes are not amateurs.

\section{Conclusion}

At its core, the conception of American democracy is based on fundamental principles of fairness and justice. From those principles flows a belief that workers should be treated with dignity and respect, valued for the contributions they make to the commercial entities, industries, businesses, and enterprises that ensure economic security for the nation and its citizens in its entirety. From the streets of the Haymarket, to the mines of West Virginia, to the farming communities of California, to the factories of the Midwest, to public schools in cities small and large, and to the playing fields of professional sports leagues, hard won battles have been fought over fair wages, health benefits, worker compensation, workplace safety, work hours, and retirement. Workers denied rights as employees are denied access to the American dream.

For over a hundred years, college athletes in the sport of football have been fighting to be recognized as employees and to be afforded access to the fruits of their labor (Oriard, 2009; Staurowsky, 2014a, 2014b). Their confrontations with coaches and college administrators have often been silenced quickly, either by their dismissal from campus; periodic concessions from the meek and inconsequential to the occasionally substantive; or through coercive tactics to keep them in line. Payment schemes to football players have taken the form of colorful euphemisms such as under the table payments, a hundred dollar handshake, and other jobs that required little to no work but resulted in a paycheck from a friend of the program. 
In the modern era, they manifest as what the NCAA refers to as student-athlete welfare programs, which speaks to the welfare state they have created to avoid outright recognition of the labor force. The migratory nature of their lives, well known to the college sport authorities who govern them, create obstacles to collective organizing because of the expanse of the workplace extending over hundreds of colleges and universities in nearly every state in the Union.

Outright confrontations between players and owners in the sport of college football are muted, covered over by the vibrant sounds and orchestrated imagery of the televised spectacle of game day and the language that emanates from the broadcast booth and all those associated with the enterprise who make sure each and every season to describe young men of military service age who are considered to be among the strongest men around that they are somehow just kids, out for a good time and a youthful lark in front of stadium audiences of over 100,000 and viewing audiences in the millions. The framing of young men as children becomes a very effective lens to ignore the demands that are placed on them, the pressures they are under, and their treatment by the people who benefit economically from their labor and the mass multibillion dollar industry that is built on their backs.

Former professional athlete Kareem Abdul Jabbar (as quoted in Luzer, 2014, para. 1) recently observed that life for college athletes "...is no longer the quaint Americana fantasy of the homecoming bonfire and a celebration at the malt shop" but a lucrative business where the players who encumber the greatest risk for permanent injuries are barred from being compensated what they are worth. It is this exact scenario that labor law in the United States was intended to address, to ensure that workers were recognized and afforded rights that emanate from that status.

The intentionality with which language has been used to weave myths that trap college football players within a system that denies them their rightful status as workers raises questions about the character of college sport officials and who so adamantly deny college football players their fundamental rights as workers.

\section{Notes}

1. The American Forensic Association, which is the governing body for college debate, does have a regulation regarding unscrupulous efforts on the part of schools to "...cause a student to transfer to it in order to transfer to it in order to receive financial compensation and/or other rewards for forensic competition" (Article 1. 3., Competitor Standards). The burden of proof in determining if a school has engaged in "unscrupulous" efforts is placed on the accusing school.

2. According to Toosi (2013), over $71 \%$ of 16 year olds and older civilians were in the workforce. In 2011, of the 19.7 million students aged 16 and over enrolled in undergraduate college, $72 \%$ worked.

\section{References}

American Forensic Association. (N.D.). Code of forensics program and forensics tournament standards for colleges and universities. Washington, DC: American Forensic Association. Retrieved from http://www.americanforensics.org/book/code-standards/ article-i-competitor-stan/code-standards

Brief of the American Council on Education, Association of Governing Boards of Universities and Colleges, Association of Public and Land-Grant Universities, College and 
University Professional Association for Human Resources, and the National Association of Independent Colleges and Universities as Amici Curiae supporting the Appellants in Northwestern University v. College Athletes Players Association (CAPA) (National Labor Relations Board, July 3, 2014).

Brief of the National Association of Collegiate Directors of Athletics and Division 1A Athletic Directors' Association supporting the Appellants in Northwestern University v. College Athletes Players Association (CAPA) (National Labor Relations Board, July, 2014).

Brief of the National Collegiate Athletic Association supporting the Appellants in Northwestern University v. College Athletes Players Association (CAPA) (National Labor Relations Board, July 3, 2014).

Brief of the National Right to Work Legal Defense and Education Foundation supporting the Appellants in Northwestern University v. College Athletes Players Association (CAPA) (National Labor Relations Board, July 3, 2014).

Brief of The Big Ten Conference, Inc. as Amicus Curiae supporting the Appellants in Northwestern University v. College Athletes Players Association (CAPA) (National Labor Relations Board, July 3, 2014).

Brief of the United States Senate Committee on Health, Education, Labor and Pensions and the United States House of Representatives Committee on Education and the Workforce as Amicus Curiae supporting the Appellants in Northwestern University v. College Athletes Players Association (CAPA) (National Labor Relations Board, July 3, 2014).

Byers, W. (1995). Unsportsmanlike conduct: Exploiting college athletes. Ann Arbor, MI: University of Michigan Press.

Cesar Chavez Foundation. (2012). Education of the heart: Quotes from Cesar Chavez. Website. Retrieved from http://www.cesarechavezfoundation.org/_board.php?mode=view\&b_ code $=001008000000000 \& b \_n o=2197$

Davis, J. (2012, October). School enrollment and work status: 2011. American Community Survey Briefs. Washington, DC: United States Census Bureau. Retrieved from http:// www.census.gov/prod/2013pubs/acsbr11-14.pdf

Finkel, R., Martin, T., \& Paley, J. (Directors). (2013). Schooled: The price of college sports. New York: Makuhari Media.

Fottrell, Q. (2013). 80\% of students work at least part-time. MarketWatch.com. Retrieved from http://www.marketwatch.com/story/nearly-4-out-of-5-students-work-2013-08-07

Jenkins v. National Collegiate Athletic Association. (2014). Retrieved from http://www. kentlaw.edu/perritt/courses/seminar/jenkins\%20v\%20NCAA_lawsuit.pdf

Luzer, D. (2014, November 14). Kareem Abdul-Jabbar takes on college athletics. Washington Monthly. Retrieved from http://www.washingtonmonthly.com/college_guide/ blog/kareem_abduljabbar_takes_on_co.php

N.A. (2014, April 28). NUMB invites high school bands to Evanston. The Buzz. Retrieved from http://northwesternbands.org/numb/buzz/99-numb-invites-high-school-bandsto-evanston\#.VGkgp_nF9qo

NCAA v. Board of Regents of University of Okla., 468 U.S. 85 (1984). Retrieved from https://www.google.com/webhp?tab=mw\&ei=8-SmVPPrDuqPsQTp6oGgAg\&ved=0 CAQQqS4oAQ\#q=ncaa+v.+board+of+regents+pdf+

NCAA Academic and Membership Affairs Staff. (2014, October). NCAA Division I Manual 2014-15. Indianapolis, IN: National Collegiate Athletic Association. Retrieved from http://www.ncaapublications.com/productdownloads/D115OCT.pdf

Northwestern 2015 Commits. (2014). 247sports.com. Retrieved from https://www.google. com/webhp?tab=mw\&ei=q6psVMD0GtjeqQb71IGwBg\&ved=0CAQQqS4oAQ\#q=n orthwestern+recruiting+class+2014

Ohr, P. S. (2014, March 26). Decision and direction of election: Northwestern University and College Athletes Players Association. Chicago, IL: National Labor Relations Board - Regional Office. Retrieved from http://www.espn.go.com/pdf/2014/0326/ espn_uniondecision.PDF 
Oriard, M. (2009). Bowled over: Big-time college football from the sixties to the BCS era. Chapel Hill, NC: University of North Carolina Press.

Pierce, D., Kubarakis, A., \& Fielding, L. (2010). The new amateurs: The National Collegiate Athletic Association's application of amateurism in a global sports arena. International Journal of Sport Management 11, 304-308.

Sack, A.L., \& Staurowsky, E.J. (1998). College athletes for hire: The evolution and legacy of the NCAA amateur myth. Westport, CT: Praeger Press.

Schwartz, A. (2014, January 6). But nobody even makes money on college sports. Slate.com. Retrieved from http://www.slate.com/articles/sports/sports_nut/2014/01/paying_college_athletes_a_point_by_point_evisceration_of_the_ridiculous.html

Southall, R., \& Staurowsky, E.J. (2013). Cheering on the collegiate model: Creating, disseminating, and imbedding the NCAA's redefinition of amateurism. Journal of Sport and Social Issues, 37(4), 403-429. doi:10.1177/0193723513498606

Staples, A. (2014, October 29). Todd Gurley will sit out two more games. Sports Illustrated. Retrieved from http://www.si.com/college-football/2014/10/29/todd-gurley-georgiabulldogs-ncaa-suspension

Staurowsky, E. J. (2013). Expert witness report: Obannon v. National Collegiate Athletic Association (on file with author).

Staurowsky, E.J. (2014a). College athletes in the age of the super conference: The case of the All Players United Campaign. Journal of Intercollegiate Sport, 7, 11-34. doi:10.1123/ jis.2013-0052

Staurowsky, E.J. (2014b, February 4). The significance of college athletes signing union cards. Huffington Post. Retrieved from http://www.huffingtonpost.com/ellen-j-staurowsky/ the-significance-of-college-athletes_b_4701486.html

Staurowsky, E.J., \& Sack, A.L. (2005). Reconsidering the use of the term "student-athlete" in academic research. Journal of Sport Management, 19, 103-117.

Toosi, M. (2013, December). Labor force projections to 2020: The labor force participation rate continues to fall. Monthly Labor Review. Washington, DC: U.S. Bureau of Labor Statistics. Retrieved from http://www.bls.gov/opub/mlr/2013/article/pdf/labor-forceprojections-to-2022-the-labor-force-participation-rate-continues-to-fall.pdf 